\title{
Sometimes, Winners Lose: \\ Economic Disparity and Indigenization in Kazakhstan
}

\author{
Ira N. Gang ${ }^{* a, b, c, e}$ and Achim Schmillen ${ }^{\mathrm{d}, \mathrm{e}}$
}

\begin{abstract}
Several post-Soviet states have introduced policies to improve the relative economic, political or social position of formerly disadvantaged populations. Using one example of such policies "Kazakhisation" in Kazakhstan - we investigate their impact on the comparative earnings of two directly affected groups, ethnic Russians and ethnic Kazakhs. Oaxaca decompositions show that Kazakhs are better endowed with income generating characteristics but receive lower returns to these characteristics than Russians. The second effect dominates and Kazakhs have comparatively lower average living standards. While "Kazakhisation" may have been successful in a narrow sense - i.e., by empowering Kazakhs to take on leading positions in the public sector - more broadly it has been a self-defeating policy as it has pushed ethnic Russians into jobs that often evolved into positions that (at least in monetary terms) are superior now to those held by Kazakhs.
\end{abstract}

JEL-Classification I32; O12; J15

Keywords: Ethnicity; Decomposition; Indigenization, Kazakhstan

\section{Draft Version 1.2}

September 2, 2014

${ }^{a}$ Rutgers University; ${ }^{\mathrm{b}} \mathrm{IZA} ;{ }^{\mathrm{c}} \mathrm{CReAM}{ }^{\mathrm{d}}$ The World Bank; ${ }^{\mathrm{e}}$ Institute for East and Southeast European Studies. ${ }^{*}$ Corresponding author; address: Ira Gang, Rutgers University, 75 Hamilton Street, New Brunswick, NJ 08901-1248, USA; Fax: +1 (732) 932 7416; email: gang@economics.rutgers.edu.

The authors thank Barbara Dietz, Myeong-Su Yun and conference participants in Munich for helpful comments and suggestions and the Volkswagen Foundation for financially supporting the collection of the Kazakhstan Migration and Remittances Survey. Part of this research was conducted while Ira Gang was a visiting fellow at the Institute for East and Southeast European Studies, whose hospitality is gratefully acknowledged. Findings, interpretations and conclusions expressed in this paper do not necessarily represent the views of the World Bank, its affiliated organizations, its Executive Directors or the governments these represent. 


\section{Introduction}

Either explicitly or implicitly, many countries have introduced policies that aim to improve the relative economic, political or social position of disadvantaged groups. Examples include "Affirmative Action" in the United States, "Reservation" in India, "Black Economic Empowerment" in South Africa and "Indigenization" policies across the newly independent states formed after the collapse of the Soviet Union (variously also called "De-Sovietization" or "De-Russification" policies). While the degree, speed, and intensity of indigenization have varied greatly across the postSoviet states, it usually involved a move away from the Russian language (Pavlenko, 2008), the reorientation of foreign policy towards the West or more recently towards China (Whitel, McAllister, Light, and Löwenhardt, 2002; İpek, 2007), and a replacement of ethnic Russian elites by "local” ones (Kuzio, 2002).

The economic effects of affirmative action or reservation have been extensively studied. In contrast, little is known about the consequences of post-Soviet indigenization policies. We aim to shrink this knowledge gap by examining the differential rates of economic achievement between ethnic Russian and ethnic Kazakh communities in resource-rich Kazakhstan. Following the breakdown of the Soviet Union, Kazakhstan gained independence. Initially struggling, by 2000 it had emerged as a rapidly growing emerging economy. At the same time, an insipid process of Kazakh indigenization (or "Kazakhisation") began to play out, with Kazakhs displacing Russians in the public sector, the armed forces and other key positions. We investigate how the interaction of a dynamic economy and indigenization policies influenced ethnic disparity in Kazakhstan.

We use monthly earnings as our measure of the economic well-being or standard of living. In the empirical analysis, we explain the variations in monthly earnings using labor market and sociodemographic characteristics of individuals as well as other variables commonly found in Mincer-type earnings equation estimations, such as the number of hours of work per week, whether an individual is self-employed or whether he or she works in the public or the private sector. Based on these regression estimates, we decompose the differences in living standards between Kazakhs and Russians in Kazakhstan using Oaxaca-type algorithms to distinguish between the proportion of the earnings gap accounted for by differences in the level of respondents' characteristics (the so-called "characteristics effect") and by differences in the impact on earnings of these characteristics (the "coefficients effect"). 
The Oaxaca-type algorithms reveal that in 2010 Kazakhs are better endowed with income generating characteristics than Russians. For instance, they are more likely to occupy managerial positions and have tertiary education. Despite these advantages, Kazakhs have lower living standards, on average, than Russians. This is because they receive returns to their characteristics that are not as high as those for Russians and that the coefficients effects dominate the countervailing characteristics effects. Our decompositions leave us with the impression that while "Kazakhisation" might have been successful in a narrow sense - i.e. by empowering Kazakhs to take on leading positions in the public sector - in a broader sense it has turned out to be a self-defeating policy by pushing ethnic Russians into jobs that by 2010 had on average evolved into more productive and at least in monetary terms superior positions than those held by many Kazakhs.

Our paper draws on the relatively small literature on economic interactions between ethnic Russians and ethnic Kazakhs in Kazakhstan. One phenomenon discussed in this literature is the large outward migration of ethnic Russians that Kazakhstan experienced in the 1990s. Becker, Musabek, Seitenova and Urzhumova (2005), for example, note that emigration of non-Kazakh ethnicities was especially high, and to a large extent influenced by political events that made Russians and other ethnicities feel unwelcome in Kazakhstan. Aldashev and Danzer (forthcoming) investigate the economic returns to bilingualism in Kazakhstan. Rather surprisingly, they find a negative effect of bilingualism on earnings. They rule out the selection of ethnicities into specific sectors as a cause, instead conjecturing that it captures individuals assessing their proficiency in a language relative to their peers and that the apparent wage penalty for bilingualism is in fact a wage penalty for being less fluent in Russian.

More broadly, our paper is also related to the much larger literature on affirmative action in the United States, reservation in India, black economic empowerment in South Africa and similar policies aimed at improving the relative economic, political or social position of disadvantaged groups. Almost universally, the policies in question tend to be highly controversial - mostly because of issues related to overall fairness and efficiency. At the same time, and in stark contrast to the conclusion of our study, the usual result reported in the empirical literature on the effects of such policies on economic disparities is that in this regard they tend to be rather effective. For instance, with respect to affirmative action policies in the United States, Holzer and Neumark (2005, p. 471) note that "[a]t this point, there seems to be little doubt that racial or gender preferences redistribute certain jobs in the labor market away from white men toward minorities and women". In similar 
fashion, reservation in India has been shown to increase the access of disadvantaged groups to political decision making (Duflo, 2005), to raise the number of women who stand for and win elected positions (Beaman, Chattopadhyay, Duflo, Pande and Topalova., 2009) and even - under certain circumstances - to significantly reduce poverty (Gang, Sen and Yun, 2008 and Chin and Prakash, 2011).

The rest of this paper is structured as follows: In Section 2, we describe the political and economic situation in Kazakhstan. Section 3 contains a description of the Kazakhstan Migration and Remittances Survey, the data set used henceforth, and a comparison of the mean characteristics of ethnic Russians and Kazakhs. What follows in Section 4 is the main empirical analysis. This consists of two parts: selection-adjusted regressions to analyze the correlates of living standards among Kazakhs and Russians and decompositions of the difference in per-capita earnings between the two ethnic groups based on the methodology developed by Oaxaca (1973). In Section 5 we examine the robustness of our results and in Section 6 we discuss possible implications for research and policy.

\section{Background Information}

Kazakhstan's vast territory covers more than one million square miles, making it the $9^{\text {th }}$ largest country in the world. At the same time, it is inhabited by a relatively small population of about 17 million people. For most of its history, the territory of modern-day Kazakhstan was inhabited by nomadic tribes. By the $16^{\text {th }}$ century, the largest of these tribes, the Kazakhs, had emerged as a distinct group. Later, the Russian Empire began its advance into Kazakhstan. Following the Russian Revolution in 1917 and the subsequent civil war, the territory became part of the Soviet Union. It was reorganized several times before acquiring its present shape, as the Kazakh Soviet Socialist Republic (SSR), in 1936.

Kazakhstan remained under Soviet rule until independence in 1991. During the Soviet regime, the government used organized recruitment and propaganda campaigns to encourage labor mobility to regions with high labor demand. At the same time a system of internal passports and residence permits (propiskas) restricted the flow of people. ${ }^{1}$ In the 1950s the Kazakh SSR received a

1 The efficiency of the USSR's government in allocating its labor force and restricting the inflow to cities has been questioned. Lewis and Rowland (1979) argue that internal labor migration responded to economic opportunities and was largely unorganized until the mid-1970s. And although the propiska system made it 
high number of immigrants from the Russian SSR and other Soviet Republic due to its rapid industrialization and the so-called Idle Land Programs (cf. Rahmonova-Schwarz, 2010). This inflow had a deep impact on the ethnic composition of Kazakhstan. At the time of the first Soviet census in 1926, indigenous Kazakhs had held the majority (58.5 percent) of the population in "their" Soviet Republic but by 1959 they accounted for only 30 percent of the population. In contrast, the Russian population share increased from 37.6 to 42.7 percent in that time period. After 1959 immigration from other Soviet Republics decreased, and between 1970 and the break-up of the Soviet Union net migration to the Kazakh SSR was negative, diminishing the Russian population share. By 1989, it was a mere 37.8 percent, which meant that at the time the Russians were marginally outnumbered by indigenous Kazakhs (39.7 percent of the population). ${ }^{2}$

In the years following independence, Kazakhstan developed the institutions of an independent country and introduced economic reforms to transform itself from a centrally planned to a market economy. These reforms were accompanied by a deep economic crisis and a huge population outflow. Between 1991 and 2001, net migration accounted for a population loss of 2.03 million persons (13 percent of the population). Many emigrants were of Russian, Ukrainian and German background and often from urban areas in the Northern and Central parts of Kazakhstan. As a consequence, the populations of most cities in Northern and Central Kazakhstan declined. What is more, those Russians who left Kazakhstan were often comparatively young and welleducated leaving remaining Russians roughly 20 years older on average than Kazakhs (Peyrouse, 2007, p. 493).

After 2000, the Kazakh economy returned to positive growth rates, driven by a booming energy sector and the implementation of institutional changes. As emigration diminished from 2002 onwards, Kazakhstan's population again began to grow. In 2009, 61 percent of Kazakhstan's inhabitants were ethnic Kazakhs, 23.7 percent were Russians and the rest belonged to a wide range of other ethnic groups including sizeable numbers of Uzbeks, Ukrainians, Tatars, Uyghurs and Germans.

difficult for Soviet citizens to move to preferred cities, these restrictions could be circumvented in a number of ways (cf. Gang and Stuart, 2002).

2 Data on the ethnic composition in the Kazakh SSR for different years are taken from Gosudarstvennyj Komitet Kazakskoj SSR po Statistike (1991). 
Compared to the large and highly volatile external migration, there has been comparatively little interregional migration since Kazakhstan's independence. The country's annual interregional migration rate of approximately one percent of the population is close to that of Russia but much smaller than what is found for the USA and Canada (cf. Andrienko and Guriev, 2004, and Danzer, Dietz, Gatskova and Schmillen, 2014). Since urbanization in Kazakhstan is still ongoing, internal movements have predominantly consisted of population flows from rural to urban areas and from small and medium cities to urban centers. As Dietz, Gatskova and Schmillen (2011) and Aldashev and Dietz (forthcoming) show, patterns of internal migration have differed between Kazakhs and Russians. In fact, during the last twenty years ethnic Russians have been much less likely to move within Kazakhstan. Those that did leave their place of residency usually also exited the country.

Together with Kazakhstan's ethno-demographic composition, the relative position in society of members of the different ethnicities has undergone fundamental change since the country's independence. As the titular nation of the Kazakh SSR, ethnic Kazakhs played a relatively prominent role in its public life even during the Soviet period. Still, Russians dominated key party and state institutions, especially in the Northern and Central parts of the republic (cf. Jones-Luong, 2002; Murphy, 2006). Moreover, the Russian language was used throughout Kazakhstan as the lingua franca. With independence, the relationship between Kazakhs, Russians and other ethnicities changed dramatically as the Kazakh government adopted a policy of what has since been called "linguistic and ethnic Kazakhization' (cf. Peyrouse, 2007, p. 481). Elements of this policy have included a 'specific status for ethnic Kazakhs; the officialisation of the Kazakh language and the disuse of Russian; ... Kazakhisation of the state administration and economy; and the exclusion of Russians from the public sector" (Peyrouse, 2007, pp. 484-485). At the same time Karin and Chebotarev (2002, p. 69) note that Kazakhization "is not recognized at the official level; as a matter of fact, it is denied".

\section{Data, Variables and Analytical Strategy}

Our analysis relies on data from the Kazakhstan Migration and Remittances Survey (KMRS). The KMRS is a household survey that was conducted in four of Kazakhstan's most important cities in 2010. It was designed by researchers from the Institute for East and Southeast European Studies (IOS) in Regensburg, Germany, and implemented in cooperation with the Center for Study of Public Opinion in Almaty, Kazakhstan. The main motivation for carrying out the survey was to explore the 
determinants, patterns and consequences of migration movements in Kazakhstan and to investigate the scope, transmission and use of remittances. ${ }^{3}$

The four cities covered by the KMRS are Almaty (Kazakhstan's largest city and its capital until 1997), Astana (the capital since 1997), Karaganda (once Kazakhstan's second city) and Pavlodar (in the northeastern part of the country). ${ }^{4}$ In altogether 2227 interviews, respondents - either the head of the household or another "influential" person in the household - were questioned about demographic and social characteristics of all household members. Together with items on migration and remittances, the core of the questionnaire encompassed questions related to the respondent's current job and employment history.

For each of the four cities, Table 1 summarizes the percentage of Russians and Kazakhs in 2010 according to our survey as well as according to data from the Statistical Agency of Kazakhstan. Both the survey and official data show that the ethnic composition of respondents differs widely between cities. While in Astana and Almaty a plurality of residents are Kazakhs, in Karaganda and Pavlodar ethnic Russians dominate. Altogether, 38.9 percent of the interviewees were ethnic Kazakhs while 45.5 percent had Russian roots. 15.2 percent belonged to other ethnic groups. These other ethnic groups are not included in the analysis below. ${ }^{5}$

\section{- Table 1 about here-}

In principle, our sample should be representative of the populations of the four cities. Yet, Table 1 shows that it seems to capture a higher proportion of Russians and a lower proportion of Kazakhs than one would expect from official statistics. That is why throughout our analysis we use weights reflecting official data on the ethnic composition in 2010 for the four cities covered by the

\footnotetext{
${ }^{3}$ For a detailed description of the KMRS, cf. Dietz and Gatskova (2011) and Dietz, Gatskova and Schmillen (2011).

${ }_{4}^{4}$ Officially, Kazakhstan's capital was relocated from Almaty to Astana largely for geographic reasons such as Almaty's high degree of air pollution and its location in a zone of strong seismic activity. However, Schatz (2003), Anacker (2004) and others suspect that the official rationale gives an incomplete picture. They provide evidence that additional motives behind the move included a desire to replace old patronage and power relationships with new ones, to create symbols of independent Kazakhstan that would resonate both inside the country and across the globe and to strengthen the Kazakh state in a part of the country traditionally dominated by ethnic Russians.

5 The relatively high percentage of ethnic Russians in the survey reflects the ethnic composition of Kazakhstan's bigger cities and is not representative for the country as a whole. As Russians traditionally settled in Kazakhstan's cities, their population share is typically higher in urban areas.
} 
KMRS (Almaty, Astana, Karaganda and Pavlodar). For similar reasons, we also weigh by the four cities' age structures and gender ratios in 2010. These weights are again based on official data.

The survey contains information on respondents' monthly earnings in 2010. While respondents could choose the currency in which they stated their earnings, we have converted all figures to tenge, Kazakhstan's currency. In 2010 one US dollar was on average worth about 152 tenge. Additionally, the survey asked about a wide range of individual characteristics useful for an analysis of earnings. These include information on labor market characteristics such as the number of hours of work per week, whether an individual was self-employed or whether he or she worked in the public or private sector. Comprehensive occupational and sectorial information is also available. For the purpose of this study, we have aggregated this information to the level of ten occupations (managers, professionals technicians, clerks, service and sales workers, agricultural workers, craft workers, plant and machine operators, elementary occupations and armed forces occupations) and six broad sectors (agriculture, mining, manufacturing, utilities, construction, services or other). Information on socio-demographic characteristics, such as a respondent's education and whether he or she was head of his or her household, are also included as are his or her gender, age and, of course, ethnicity. Lastly, the interview included a series of questions on the composition of respondents' households. This allows us to account for selection into labor force participation. ${ }^{6}$

Although the KMRS is not longitudinal, it provides detailed retrospective information on respondents and - to a more limited extent - their households for the years 1991 and 2001. For example, respondents are asked about whether they worked during November of these two years. If the answer is yes, questions about monthly earnings and job characteristics for that particular point in time follow.

\section{- Table 2 about here-}

Basic summary statistics for various variables related to earnings and labor market and sociodemographic characteristics are presented in Table 2. The table displays the means and standard deviations of the variables for the year 2010 separately for Russians and Kazakhs. Additionally, results of t-tests for differences in characteristics between the two groups are presented.

${ }^{6}$ Formally, participation includes the employed and unemployed. However, most studies on labor supply do not count the unemployed in the definition of participation even though they still use the term 'participation'. We follow this convention. 
Table 2 shows that our sample contains 992 Russians and 835 Kazakhs and that average values for a number of variables used differ significantly between the two ethnicities. Maybe most strikingly, the Russians in the sample have significantly higher average monthly earnings than the Kazakhs. On average, Russians earn 62,065 tenge (that is 408 US dollars) a month and Kazakhs 57,927 tenge (or 381 US dollars). This earnings gap is statistically significant at the five percent level. Concerning other labor market, occupation or sector characteristics, Russians are less likely than Kazakhs to be employed by a state enterprise. This is the case for 28.9 percent of Russian and for 41.5 percent of Kazakh interviewees. Russians are also less likely to pursue an armed forces occupation (1.1 vs. 4.8 percent) but more likely to work in the utilities sector (7.8 vs. 4.2 percent). Finally, a lower proportion of Russian respondents have a tertiary education: 41.2 percent of Kazakhs and 32.3 percent of Russians have completed college or university. In general, high rates of secondary and tertiary education reflect the high average level of formal education achieved in the Soviet Union and maintained in the states that emerged after its break-up.

\section{Results}

To investigate economic disparities between Kazakhs and Russians in 2010, we employ the regression-based decomposition analysis due to Oaxaca (1973) using the implementation in the Stata ado file oaxaca by Jann (2008). Initially, we estimate the correlates of log monthly earnings for Kazakhs and Russians. In order to account for possible selection into the labor force, we use a twostage Heckman selection model (Heckit). Thereafter, we decompose the difference in mean monthly earnings of the two ethnic groups, highlighting the relative roles of differences in characteristics and coefficients in explaining these differences in earnings.

The explanatory variables in our earnings equations are age, age-squared and gender of the respondent, indicators for whether he or she is the household head and for his or her educational attainment. Additional controls include hours of work per week and dummies for self-employment and employment by a state enterprise. Furthermore, we add controls to account for occupation, sector of employment and the four Kazakh cities where the KMRS was carried out. When estimating the selection equations for labor force participation, we again control for an individuals' socio-

\footnotetext{
${ }^{7}$ Our exposition of the Oaxaca decomposition analysis follows Bhaumik, Gang and Yun (2006).
} 
demographic characteristics, education and location. In addition to that, family characteristics - an individual's marital status and the proportion of children and seniors in his or her household - are used as instruments. That is, these explanatory variables appear in the selection equation but not in the earnings equation. This specification borrows significantly from the literature on labor supply and earnings, e.g. from Dimova and Gang (2004).

\section{- Table 3 about here-}

Coefficients and robust standard errors of both stages of the Heckit regressions are reported in Table 3 (including the one for the inverse Mill's ratio). The table shows that for both Russians and Kazakhs average earnings are higher for the self-employed and for those working in the private sector, ceteris paribus. ${ }^{8}$ Also for both groups, earnings tend to increase with age but at a declining rate. Thus, over the life cycle earnings exhibit an inverse u-shaped path. Equally plausibly, earnings are on average higher for those working more hours per week. If one compares earnings by gender one finds that average earnings are higher for men. The gender earnings gap is 26.2 percent for Russians and 18.7 percent for Kazakhs. Concerning the education variables, earnings tend to be higher for those with higher educational attainment. In both estimating equations, individuals with tertiary education on average earn 39.4 percent more than those with only compulsory education. When it comes to occupations, mean earnings are lowest for elementary occupations and highest for managers (the reference category in Table 4). Again, this is the case irrespective of whether correlates of log monthly earnings are estimated for Russian or for Kazakh respondents

For a number of other variables, patterns differ between Russians and Kazakhs. In particular, average earnings for Kazakhs are highest in Astana while for Russians they are about equally high in Astana and Almaty and much lower in Karaganda and Pavlodar. Besides, sector variables appear to be statistically significantly correlated with monthly earnings only for the sample comprising Russian individuals. For this sample, individuals employed in the mining sector have the highest earnings followed by those in the construction sector. All else being equal, average earnings in the mining sector are 64.7 percent higher than in the agricultural sector (the baseline category).

\footnotetext{
${ }^{8}$ Using the 1996 World Bank Living Standards Measurement Survey, Verme (2000) documented that income opportunities between the private sector and self-employment were roughly similar in Kazakhstan. For 2010, i.e. "only" 14 years later, we document an earnings premium of self-employment of between 19 and 27 percent. This underlines the dynamism and quickly changing nature of Kazakhstan's labor market.
} 
In spite of some important differences between correlates of log monthly earnings for Russians and Kazakhs, altogether the patterns associated with individual earnings look rather similar for the two groups. Moreover, the direction and size of the individual coefficients are generally what one would expect from the estimation of traditional Mincer-type equations.

We account for possible selection into the labor force. Above we mentioned that the regressions of Table 3 use family characteristics (an individual's marital status and the proportion of children and seniors in the household) as instruments. For Russians, some of these instruments are statistically significant. For instance, respondents in households with a higher proportion of individuals aged five or under or 66 or over tend to be less likely to work. Also for the Russian sample, the inverse Mill's ratio is marginally significant which provides weak evidence that selection into the labor force actually takes place. For Kazakhs, the inverse Mill's ratio is not statistically significant and neither are the instruments.

\section{- Table 4 about here -}

Though all in all there is only limited evidence that selection into the labor force is indeed an issue we need to worry about, our benchmark decomposition is based on the Heckit estimations of Table 3. We consider this a precautionary measure. As an alternative, Table 4 shows correlates of log monthly earnings estimated with OLS instead of Heckit. The table demonstrates that at least qualitatively but for the most part also quantitatively earnings equations look very similar using either estimation method. ${ }^{9}$

To investigate the relative influences of the characteristics and the coefficients effects on the differences in the average levels of monthly earnings between Kazakhs and Russians, we use the stylized Oaxaca decomposition algorithm. ${ }^{10}$ The Oaxaca decomposition equation is written as:

$$
\bar{Y}_{A}-\bar{Y}_{B}=\left(X_{A}-\bar{X}_{B}\right) \beta_{A}+\bar{X}_{B}\left(\beta_{A}+\beta_{B}\right)+\bar{e}_{A}-\bar{e}_{B}
$$

\footnotetext{
9 When using oaxaca with heckmam Jann (2008) adjusts the decomposition for the specified selection; the decomposition is performed on the predicted earnings gap. Yun (2007) shows how to implement an exact decomposition of the actual gap by inclusion of a residual effect, if desired. As the Heckit and OLS here produce very close results it is not necessary to consider this difference.

10 The Oaxaca decomposition was introduced to study racial or gender wage differentials using regression analysis to generate the characteristics and coefficients effects. However, this approach has been extended and can be applied to studying regression-based differences of individuals, households, or firms.
} 
where $\bar{Y}_{j}$ denotes average log monthly earnings and $\bar{X}_{j}$ is a $1 \times K$ vector of average individual characteristics of group $j(A$ or $B) . \beta_{j}$ is a $K \times 1$ vector of parameters and $\bar{e}_{j}$ the average error term which is zero by construction. The first, second, and third components of the right-hand side of the equation are called the characteristics, the coefficients and the residuals effects, respectively.

\section{- Table 5 about bere-}

Results from an Oaxaca decomposition based on the selection-corrected estimates from Table 3 are reported in Table 5. ${ }^{11}$ The overall (predicted) difference in the logarithm of monthly earnings between Kazakhs and Russians individuals is -0.171 . That is, we need to explain why in 2010 ethnic Russians on average earned 17.1 percent more per month than Kazakhs. ${ }^{12}$

The overall characteristics and coefficients effects from the decomposition analysis are 0.041 and $-0.212 \log$ points, respectively. The positive value of the characteristics effect means that, if Kazakhs and Russians were to have the same regression coefficients, i.e., the impact of the characteristics on their living standards were identical, the logarithm of monthly earnings of Kazakhs would have been higher than that of Russians by 0.041 log points due solely to differences in characteristics. However, the coefficients effect of -0.212 implies that, if both Kazakhs and Russians were to have the same characteristics so that any difference in earnings between the two ethnic groups would be due only to differences in the regression coefficients, e.g., the rates of return on the characteristics, the logarithm of monthly earnings of Kazakhs would have been lower than that of Russians by $0.212 \mathrm{log}$ points. In short, Kazakhs would be worse off if the differences between their characteristics and those of the Russian individuals were to disappear. However, they would be better off in the absence of any differences between the two groups in the effectiveness of, or returns to, those characteristics.

\footnotetext{
${ }^{11}$ For the moment, the Russian coefficients will be used as the reference coefficients. In section 5, we will explore whether our main results are robust to using the Kazakh coefficients as the reference coefficients instead.

${ }^{12}$ An often useful alternative interpretation is offered on the tables under the columns "Share" but suppressed in the text. Here we set the gap of 0.171 at $100 \%$ and show the each items contribution to explaining this gap. Thus "Share" refers to the ratio of the contribution of each factor to the overall differences in monthly earnings of $-0.171 \mathrm{log}$ points between Kazakhs and Russians; it is expressed as a percentage of this difference.
} 
The coefficients effect generally incorporates the effect of the constant term. The coefficients of the constant terms explain the gap between Kazakhs and Russians that is not attributed to controlling or explanatory variables. Hence, the difference in the constant terms may be interpreted as baseline differences between the two ethnic communities. We can separate the effect of the constant term from the effects of the other coefficients by rewriting (1) as:

$$
\bar{Y}_{A}-\bar{Y}_{B}=\sum_{k=1}^{K}\left(\bar{X}_{A}^{k}-\bar{X}_{B}^{k}\right) \beta_{A}^{k}+\left(\beta_{A}^{1}-\beta_{B}^{1}\right)+\sum_{k=2}^{K} \bar{X}_{B}^{k}\left(\beta_{A}^{k}-\beta_{B}^{k}\right)+\bar{e}_{A}-\bar{e}_{B}
$$

where $\beta_{j}^{1}$ is the constant term for group $j(A$ or $B)$. The result of this partitioning is also reported in Table 5. Both the characteristics effect and the coefficients effect of the controlling or explanatory variables favor the Kazakhs. The latter is not statistically significant, though. The effect of the constant term overwhelmingly favors Russians but is again not statistically significant.

We can decompose the characteristics and the coefficients effects into subgroups of variables or even individual variables. In this context, a critical issue is that the decomposition results for categorical variables depend on which category is chosen to be the omitted base category. To arrive at decomposition results that are independent of such a choice, we make use of a method introduced by Yun (2005) and included in the Stata ado file oaxaca by Jann (2008). This method relies on first estimating the group models with the standard dummy coding. Next, the coefficient vectors are transformed so that they represent deviations from the grand mean and the coefficient for the base category is added.

As reported in Table 5, disaggregating the characteristics effect shows that Kazakhs benefit from working more hours per week, from having socio-demographic characteristics more favorable for the labor market (this is for the most part due to the comparatively lower average age of Kazakhs living in Kazakhstan mentioned above), from being more likely to be managers, and from having a generally higher level of education. On the other hand, Russians have the advantages of being less likely to be employed by state enterprises and of being more likely to reside in a favorable location. As mentioned above, the overall characteristics effect works in the Kazakhs' favor.

Concerning the detailed decomposition of the coefficients effect, much fewer variables are statistically significant. Of those that are, the returns to labor market characteristics favor the Russians while those related to occupations and locations work in the Kazakhs' favor. It should be noted, however, that all these coefficients are significant only at the ten percent level and that, as 
already mentioned, the overall coefficients effect net of baseline differences between the two ethnic communities is statistically significant not even at this level.

The results reported in Table 5 imply that Kazakhs, i.e. those individuals belonging to the ethnicity that dominates Kazakhstan and forms its titular nation, tend to have more favorable characteristics than Russians but still earned less. By empowering Kazakhs and enabling them to gain relatively favorable characteristics, Kazakhization has apparently been successful in a relatively narrow sense. At the same time, in economic terms Kazakhization has been a somewhat selfdefeating policy. This appears almost ironic.

However, one might wonder whether the higher average earnings of Russians in 2010 are really a result of Kazakhization policies. An alternative explanation would be that they are in fact due to Russia's history as an always dominant and at times out-rightly colonial power in central Asia. This competing explanation might imply that in the absence of Kazakhization policies, earnings of ethnic Russians would be even more elevated compared to Kazakhs than is already the case today. ${ }^{13}$

We cannot do Oaxaca type decomposition for the counterfactual situation of Kazakhstan's labor market in 2010 without Kazakhization policies. However, we can test a corollary of the hypothesis that higher earnings for Russians are a legacy of their historic dominance in Central Asia. As mentioned above, our data set contains retrospective information for 1991 and 2001 and if this competing theory is correct we should see even larger earnings advantages for ethnic Russians for 1991 and 2001 than for 2010.

\section{- Table 6 about here-}

Table 6 shows the outputs of corresponding Oaxaca decompositions for the differences in monthly earnings between Kazakhs and Russians for 1991 and 2001. Because we do not have any instruments for these two years we are unable to control for selection into the labor force. Instead, Table 6 relies on decompositions based on OLS regressions. For comparison purposes, it also reports an OLS-based decomposition for 2010.

\footnotetext{
13 The relative economic conditions of Russians and Kazaks might also look very different if the economic transition had played out differently and had not favored private sector instead of public sector jobs or had rewarded individuals' characteristics differently.
} 
Contrary to what is implied by the competing explanations, what we find is that the Russians in our sample generally earned less than the Kazakhs in both 1991 and 2001. As discussed above large numbers of Russians left Kazakhstan during the 1990s and these emigrants were generally younger and better educated. It is quite possible that in 1991 (especially) ethnic Russian earnings were on average higher than ethnic Kazakh earnings. But for our sample of ethnic Russian stayers this is not true. Yet, they are doing better than Kazakhs by 2010. These ethnic Russians' higher earnings in 2010 can probably not be explained by the imperial legacy of Russia and the Soviet Union. Instead, our decompositions really leave us with the impression that while Kazakhization might have been successful in a narrow sense - e.g. by empowering Kazakhs to take on leading positions in the public sector - in a broader sense it turned out to be a self-defeating policy because it pushed Russians into jobs that by 2010 had on average evolved into superior positions (at least in monetary terms) than those held by Kazakhs.

\section{Robustness}

Table 7 offers three alternative specifications of our benchmark Oaxaca type decomposition of log monthly earnings in 2010. The objective is to assess whether our results are robust to variations in the empirical setup. For conciseness, outputs are displayed only for the aggregate characteristics and coefficient effects as well as for semi-detailed decompositions that group the effects of labor market characteristics, socio-demographic characteristics, occupations, sectors and education. Outputs for the detailed decompositions are available upon request.

\section{- Table 7 about here -}

So far sampling weights have been used throughout the analysis. As mentioned above, these are based on official data on the ethnic composition, age structure and gender ratio in 2010 for the four cities covered by the KMRS (Almaty, Astana, Karaganda and Pavlodar). One concern might be whether such official data can always be seen as reliable. Therefore, sampling weights are removed in the first panel of Table 7. In the table's second panel the sample composition is altered. While previously all observations with valid information for all relevant variables for 2010 were used, the panel now restricts the analysis to a 'balanced' sample. That is, it only compromises individuals that were of working age in 1991, 2001 and 2010 and for whom we have consistent information on labor market status and characteristics for all three years. Finally, the third panel of Table 7 performs the 
Oaxaca type decomposition not with Russian but with Kazakh coefficients. This is a standard sensitivity check to test whether results are robust to using the coefficients of one group instead of the other.

The different panels of Table 7 make it clear that for all three alternative specifications predicted average monthly earnings are higher for Russians than for Kazakhs. The magnitude of the difference in these monthly earnings is quite robust as well. Moreover, the signs of aggregate characteristics and coefficients effects stay similar as do those of almost all semi-aggregate variables' effects (or at least of those that are statistically significant). What does vary somewhat is the exact magnitude and level of statistical significance of some variables' characteristics and coefficient effects.

\section{Conclusions}

Using the Kazakhstan Migration and Remittances Survey (KMRS), we investigated the comparative earnings of ethnic Russians and ethnic Kazakhs in 2010. Following independence from the Soviet Union in 1991, many ethnic Russians left Kazakhstan. In parallel, over the last twenty years ethnic Kazakhs have come to dominate many of the key economic and political positions that had formerly been occupied by ethnic Russians. This had the consequence that by 2010 Russians in our sample were less likely to be employed by a state enterprise, less likely to pursue an armed forces occupation and less likely to have a tertiary education. In spite of all this, in contrast to 1991 and 2001, by 2010 ethnic Russians were earning more than ethnic Kazakhs.

We explained this apparent puzzle using Oaxaca type decompositions. These showed that while in 2010 Kazakhs were better endowed with income generating characteristics (e.g. they benefited from being more likely to be managers and to have tertiary education) but received returns to these characteristics that were not as high as those of Russians (both overall and with respect to specific characteristics such as those related to the labor market and certain sectors). In the aggregate, the coefficients effect dominated and Kazakhs had comparatively lower average earnings. Our decompositions left us with the impression that while "Kazakhisation" might have been successful in a narrow sense - e.g. by empowering Kazakhs to take on leading positions in the public sector - in a broader sense it has turned out to be a self-defeating policy by pushing ethnic Russians into jobs that 
by 2010 had on average evolved into superior positions - at least in monetary terms - than those held by Kazakhs.

Our result of a self-defeating indigenization strategy is in stark contrast to the conclusions reached by much of the empirical literature on the effects of policies aimed at improving the situation of disadvantaged groups which usually finds these policies to be rather effective. Moreover, it appears almost ironic that Kazakhs, i.e. those individuals belonging to the ethnicity that dominates Kazakhstan and forms its titular nation, tend to have more favorable characteristics than Russians but still earn less. 


\section{References}

Aldashev, Alisher and Alexander M. Danzer. forthcoming. "Bilinguality and Economic Performance." in Wickström, B.-A. and M. Gazzola (eds.), Economics and Language Policy, MIT Press.

Aldashev, Alisher. and Barbara Dietz. Forthcoming. "Economic and Spatial Determinants of Interregional Migration in Kazakhstan.” Economic Systems.

Anaker, Shonin. 2004. “Geographies of Power in Nazarbayev's Astana.” Eurasian Geography and Economics, 45, 7: 515-533.

Andrienko, Yuri and Sergei Guriev. 2007. "Determinants of Interregional Mobility in Russia: Evidence from Panel Data." Economics of Transition, 12, 1: 1-27.

Bhaumik, Sumon K., Gang, Ira N. and Myeung-Su Yun. 2006. "Ethnic conflict and economic disparity: Serbians and Albanians in Kosovo.” Journal of Comparative Economics, 34: 754-773.

Beaman, Lori, Raghebendra Chattopadhyay, Esther Duflo, Rohini Pande and Petia Topalova. 2009. "Powerful Women: Does Exposure Reduce Bias?" The Quarterly Journal of Economics, 124, 4: 1497-1540.

Becker, Charles M., Erbolat N. Musabek, Ai-Gul S. Seitenova and Dina S. Urzhumova. 2005. “The Migration Response to Economic Shock: Lessons from Kazakhstan.” Journal of Comparative Economics, 33, 1: 107-132.

Blinder, Alan S. 1973. "Wage discrimination: Reduced form and structural estimates." Journal of Human Resources, 8: 436-455.

Chin, Aimee and Nishith Prakash. 2011. "The Redistributive Effects of Political Reservation for Minorities: Evidence from India.” Journal of Development Economics, 96, 2: 265-277.

Danzer, Alexander M., Barbara Dietz, Kseniia Gatskova and Achim Schmillen. 2014. "Showing off to the New Neighbors? Socio-Economic Status, Income and Consumption Patterns of Internal Migrants.” Journal of Comparative Economics 42, 1: 230-245.

Dietz, Barbara and Kseniia Gatskova. 2011. "Migration and Remittances in Kazakhstan: Survey Technical Report.” Osteuropa-Institut Regensburg, Working Paper 303.

Dietz Barbara, Kseniia Gatskova and Achim Schmillen. 2011. "Migration and Remittances in Kazakhstan: First Evidence from a Household Survey.” Osteuropa-Institut Regensburg, Working Paper 304.

Dimova, R. and I. Gang. 2007. "Self-Selection and Earnings During Volatile Transition." Journal of Comparative Economics 35(3) 612-629.

Duflo, Esther. 2005. "Why Political Reservations?" Journal of the European Economic Association, 3, 2-3: 668-678.

Gang Ira N. and Robert C. Stuart, 2002. "The Political Economy of Russian City Growth." Economic Development and Cultural Change, 50, 3: 491-508.

Gang, Ira N., Kunal Sen, and Myeong-Su Yun, 2008. "Poverty in rural India: caste and tribe." Review of Income and Wealth 54, 1: 50-70.

Gosudarstvennyj Komitet Kazakskoj SSR po Statistike. 1991. "Ob osnovnych pokazateljach vsesojuznych perepisej naselenija 1939, 1959, 1970, 1979 i 1989 gg.” Alma-Ata.

Holzer, Harry J. and David Neumark. 2006. “Affirmative Action: What Do We Know?.” Journal of Policy Analysis and Management, 25, 2: 463-490. 
İpek, Pinar. 2007. "The role of oil and gas in Kazakhstan's foreign policy: Looking east or west?" Europe-Asia Studies, 59, 7:1179-1199.

Jann, Ben. 2008. "The Blinder-Oaxaca decomposition for linear regression models." The Stata Journal, 8, 4: 453-479.

Jones-Luong, Pauline. 2002. Institutional Change and Political Continuity in Post-Soviet Central Asia: Power, Perceptions, and Pacts. Cambridge.

Karin, E. and A. Chebotarev. 2002. "The Policy of Kazakhization and Government Institutions in Kazakhstan." in Masanov N., Karin E., Chebotarev A. and N. Oka (eds.), The Nationalities Question in Post-Soviet Kazakhstan, Institute for Developing Economies, Tokyo, Japan: 69-108.

Kuzio, Taras. 2002. "History, Memory and Nation Building in the Post-Soviet Colonial Space." Nationalities Papers, 30, 2:241-264.

Lewis Robert A. and Richard H. Rowland. 1979. Population Redistribution in the USSR: its impact on society, 1897-1977. New York.

Murphy, Jonathan. 2006. "Illusory Transition? Elite Reconstitution in Kazakhstan, 1989-2002." Europe-Asia Studies, 58, 4: 523-554.

Oaxaca, Ronald L. 1973. "Male-Female Differentials in Urban Labor Markets." International Economic Review, 14: 693-709.

Oaxaca, Ronald L., and Michael R. Ransom. 1999. "Identification in detailed wage decompositions." Review of Economics and Statistics, 81: 154-157.

Pavlenko, Aneta. 2008. "Russian in post-Soviet countries” Russian Linguistics 32: 59-80.

Peyrouse, Sébastien. 2007. "Nationhood and the Minority Question in Central Asia: The Russians in Kazakhstan.” Europe-Asia Studies, 59, 3: 481-501.

Rahmonova-Schwarz, Delia. 2010. "Migrations during the Soviet Period and in the Early Years of USSR'S Dissolution: A Focus on Central Asia." Revue Européenne des Migrations Internationales, 26, 3: 9-30.

Schatz, Edward. 2003. "When Capital Cities Move: The Political Geography of Nation and State Building." Helen Kellogg Institute for International Studies, Working Paper 303.

Verme, Paolo. 2000. "The Choice of the Working Sector in Transition - Income and Non-income Determinants of Sector Participation in Kazakhstan." Economics of Transition, 8, 3: 691-731.

White, Stephen, Ian McAllister, Margot Light and John Löwenhardt. 2002. "A European or a Slavic Choice? Foreign Policy and Public Attitudes in Post-Soviet Europe.” Europe-Asia Studies, 54, 2:181202.

Yun, Myeung-Su. 2005. "A Simple Solution to the Identification Problem in Detailed Wage Decompositions.” Economic Inquiry, 43: 766-772.

Yun, Myeung-Su. 2007. "An extension of the Oaxaca decomposition using generalized residuals." Journal of Economic and Social Measurement," 32, 1: 15-22. 


\section{Tables}

Table 1

Ethnic composition in the KMRS and the city population in Kazakhstan (2010)

\begin{tabular}{lllllll}
\hline & \multicolumn{2}{l}{ Kazakh (in percent) } & \multicolumn{2}{l}{ Russian (in percent) } & \multicolumn{2}{l}{ Other (in percent) } \\
\hline & KMRS & Population & KMRS & Population & KMRS & Population \\
\hline Almaty & 47.3 & 51.7 & 38.6 & 33.5 & 14.1 & 14.8 \\
Astana & 51.7 & 65.2 & 35.2 & 23.8 & 13.1 & 11.0 \\
Karaganda & 21.7 & 35.4 & 60.1 & 46.2 & 18.2 & 18.4 \\
Pavlodar & 30.7 & 37.4 & 51.4 & 46.4 & 17.9 & 15.9 \\
All & 38.9 & 61.1 & 45.5 & 23.7 & 15.2 & 14.9 \\
\hline
\end{tabular}

Sources: Statistical Agency of Kazakhstan; own calculations based on KMRS 
Table 2

Characteristics of the Individuals and t-Tests for Differences in these Characteristics (2010)

\begin{tabular}{|c|c|c|c|c|c|}
\hline \multirow{2}{*}{ Earnings } & \multicolumn{2}{|c|}{ Russians } & \multicolumn{2}{|c|}{ Kazakhs } & \multirow[t]{2}{*}{ t-Tests } \\
\hline & & & & & \\
\hline Monthly earnings in Tenge & 62,065 & $(1742.8)$ & 57,664 & $(1422.5)$ & $* *$ \\
\hline \multicolumn{6}{|l|}{ Labor market characteristics } \\
\hline Self-employed & 0.0277 & $(0.0055)$ & 0.0303 & $(0.0073)$ & \\
\hline State enterprise & 0.2917 & $(0.0203)$ & 0.4227 & $(0.0261)$ & $* * *$ \\
\hline Private sector & 0.5338 & $(0.0261)$ & 0.6617 & $(0.0210)$ & $* * *$ \\
\hline Hours per week & 44.077 & $(0.5427)$ & 44.971 & $(0.6440)$ & \\
\hline \multicolumn{6}{|l|}{ Socio-demographic characteristics } \\
\hline Male & 0.4175 & $(0.0176)$ & 0.5168 & $(0.0222)$ & $* * *$ \\
\hline Age & 48.494 & $(0.5764)$ & 43.113 & $(0.6652)$ & $* * *$ \\
\hline Head of household & 0.7533 & $(0.0141)$ & 0.7421 & $(0.0187)$ & \\
\hline \multicolumn{6}{|l|}{ Occupation } \\
\hline Managers & 0.0956 & $(0.0124)$ & 0.1021 & $(0.0143)$ & \\
\hline Professionals & 0.1961 & $(0.0169)$ & 0.2212 & $(0.0214)$ & \\
\hline Technicians and associate professionals & 0.0730 & $(0.0111)$ & 0.0639 & $(0.0121)$ & \\
\hline Clerical support workers & 0.0963 & $(0.0127)$ & 0.1009 & $(0.0149)$ & \\
\hline Service and sales workers & 0.1318 & $(0.0140)$ & 0.1429 & $(0.0186)$ & \\
\hline $\begin{array}{l}\text { Skilled agricult., forestry and fishery } \\
\text { workers }\end{array}$ & 0.0013 & $(0.0013)$ & 0.0048 & $(0.0040)$ & \\
\hline Craft and related trades workers & 0.1428 & $(0.0156)$ & 0.1157 & $(0.0170)$ & \\
\hline $\begin{array}{l}\text { Plant and machine operators, and } \\
\text { assemblers }\end{array}$ & 0.1021 & $(0.0136)$ & 0.0720 & $(0.0142)$ & \\
\hline Elementary occupations & 0.1518 & $(0.0164)$ & 0.1280 & $(0.0189)$ & \\
\hline Armed forces occupations & 0.0092 & $(0.0040)$ & 0.0485 & $(0.0110)$ & $* * *$ \\
\hline \multicolumn{6}{|l|}{ Sector } \\
\hline Agriculture & 0.0079 & $(0.0036)$ & 0.0145 & $(0.0066)$ & \\
\hline Mining & 0.0279 & $(0.0067)$ & 0.0281 & $(0.0067)$ & \\
\hline Manufacturing & 0.1074 & $(0.0134)$ & 0.0807 & $(0.0153)$ & \\
\hline Utilities & 0.0776 & $(0.0127)$ & 0.0422 & $(0.0110)$ & $* *$ \\
\hline Construction & 0.0785 & $(0.0122)$ & 0.0965 & $(0.0159)$ & \\
\hline Services/other & 0.7007 & $(0.0202)$ & 0.7380 & $(0.0239)$ & \\
\hline \multicolumn{6}{|l|}{ Education } \\
\hline Low education & 0.1486 & $(0.0137)$ & 0.1073 & $(0.0147)$ & $* *$ \\
\hline Medium education & 0.5283 & $(0.0178)$ & 0.4853 & $(0.0223)$ & \\
\hline High education & 0.3231 & $(0.0162)$ & 0.4075 & $(0.0214)$ & $* * *$ \\
\hline \multicolumn{6}{|l|}{ Location } \\
\hline Astana & 0.1158 & $(0.0083)$ & 0.1398 & $(0.0099)$ & $*$ \\
\hline Almaty & 0.2644 & $(0.0171)$ & 0.2085 & $(0.0135)$ & $* *$ \\
\hline Karaganda & 0.2723 & $(0.0146)$ & 0.2336 & $(0.0197)$ & \\
\hline Pavlodar & 0.3474 & $(0.0176)$ & 0.4181 & $(0.0234)$ & $* *$ \\
\hline Number of individuals & 992 & & 835 & & \\
\hline
\end{tabular}

Notes: (1) The figures within the parentheses are linearized standard errors.

(2) The symbols *, ** and *** indicate significance at the $10 \%, 5 \%$ and $1 \%$ levels, respectively.

(3) Weights have been used. 
Table 3

Determinants of monthly earnings of Russians and Kazakhs in 2010: Heckit estimation

\begin{tabular}{|c|c|c|c|c|c|c|}
\hline & \multicolumn{3}{|l|}{ Russians } & \multicolumn{3}{|l|}{ Kazakhs } \\
\hline & \multicolumn{2}{|l|}{ Estimate } & \multirow[t]{2}{*}{ S.E. } & \multicolumn{2}{|l|}{ Estimate } & \multirow[t]{2}{*}{ S.E. } \\
\hline \multicolumn{5}{|l|}{ Earnings Equation } & & \\
\hline \multicolumn{7}{|l|}{ Labor market characteristics } \\
\hline Self-employed & 0.2667 & $* *$ & $(0.1214)$ & 0.1889 & $*$ & $(0.1124)$ \\
\hline State enterprise & -0.0850 & $*$ & $(0.0448)$ & -0.0895 & $*$ & $(0.0519)$ \\
\hline Hours per week & 0.0078 & $* * *$ & $(0.0018)$ & 0.0034 & $*$ & $(0.0018)$ \\
\hline \multicolumn{7}{|l|}{ Socio-demographic characteristics } \\
\hline Male & 0.2622 & $* * *$ & $(0.0468)$ & 0.1868 & $* * *$ & $(0.0530)$ \\
\hline Age & 0.0261 & $*$ & $(0.0135)$ & 0.0424 & $* *$ & $(0.0184)$ \\
\hline $\operatorname{Age}^{\wedge} 2$ & -0.0003 & $*$ & $(0.0002)$ & -0.0006 & $* *$ & $(0.0002)$ \\
\hline Head of household & 0.0644 & & $(0.0476)$ & 0.1279 & $*$ & $(0.0673)$ \\
\hline \multicolumn{7}{|l|}{ Occupation } \\
\hline Professionals & -0.1446 & $*$ & $(0.0737)$ & -0.0577 & & $(0.0709)$ \\
\hline Technicians and associate professionals & -0.1542 & $*$ & $(0.0919)$ & 0.0231 & & $(0.0799)$ \\
\hline Clerical support workers & -0.2216 & $* * *$ & $(0.0794)$ & -0.1703 & $*$ & $(0.0893)$ \\
\hline Service and sales workers & -0.2448 & $* * *$ & $(0.0812)$ & -0.2466 & $* * *$ & $(0.0827)$ \\
\hline \multicolumn{7}{|l|}{ Skilled agricult., forestry and fishery } \\
\hline & -0.1771 & & $(0.1241)$ & -0.4604 & $* * *$ & $(0.1513)$ \\
\hline Craft and related trades workers & -0.2656 & $* * *$ & $(0.0787)$ & -0.0103 & & $(0.0916)$ \\
\hline & \multicolumn{6}{|c|}{ Plant and machine operators, and } \\
\hline Elementary occupations & -0.3554 & $* * *$ & $(0.0778)$ & -0.2569 & $* * *$ & $(0.0875)$ \\
\hline Armed forces occupations & -0.0207 & & $(0.1751)$ & -0.0097 & & $(0.0916)$ \\
\hline \multicolumn{7}{|l|}{ Sector } \\
\hline Mining & 0.6468 & $* * *$ & $(0.1321)$ & 0.1241 & & $(0.1596)$ \\
\hline Manufacturing & 0.1719 & $*$ & $(0.0984)$ & 0.1409 & & $(0.1377)$ \\
\hline Utilities & 0.2090 & $*$ & $(0.1169)$ & 0.0169 & & $(0.1620)$ \\
\hline Construction & 0.2415 & $* *$ & $(0.1019)$ & 0.0707 & & $(0.1394)$ \\
\hline Services/other & 0.1310 & & $(0.0886)$ & -0.0065 & & $(0.1217)$ \\
\hline \multicolumn{7}{|l|}{ Education } \\
\hline Medium education & 0.1917 & $* * *$ & $(0.0569)$ & 0.1738 & $* *$ & $(0.0745)$ \\
\hline High education & 0.3934 & $* * *$ & $(0.0663)$ & 0.3943 & $* * *$ & $(0.0821)$ \\
\hline \multicolumn{7}{|l|}{ Location } \\
\hline Astana & 0.0363 & & $(0.0581)$ & 0.1439 & $* *$ & $(0.0577)$ \\
\hline Karaganda & -0.3149 & $* * *$ & $(0.0558)$ & -0.0779 & & $(0.0673)$ \\
\hline Pavlodar & -0.3144 & $* * *$ & $(0.0538)$ & -0.1977 & $* * *$ & $(0.0655)$ \\
\hline Constant & 9.8457 & $* * *$ & $(0.3321)$ & 9.6075 & $* * *$ & $(0.4355)$ \\
\hline Number of individuals & & 637 & & & 597 & \\
\hline
\end{tabular}


Selection Equation

\begin{tabular}{|c|c|c|c|c|c|c|}
\hline \multicolumn{7}{|l|}{ Location } \\
\hline Astana & \multicolumn{2}{|l|}{-0.1384} & $(0.1700)$ & \multicolumn{2}{|l|}{0.1985} & $(0.1449)$ \\
\hline Karaganda & \multicolumn{2}{|l|}{-0.1010} & $(0.1454)$ & \multicolumn{2}{|l|}{0.2388} & $(0.1869)$ \\
\hline Pavlodar & \multicolumn{2}{|l|}{-0.0158} & $(0.1543)$ & \multicolumn{2}{|l|}{0.0719} & $(0.1653)$ \\
\hline \multicolumn{7}{|l|}{ Socio-demographic characteristics } \\
\hline Male & 0.6581 & $* * *$ & $(0.1335)$ & 0.2781 & $*$ & $(0.1640)$ \\
\hline Age & 0.1730 & $* * *$ & $(0.0290)$ & 0.2241 & $* * *$ & $(0.0342)$ \\
\hline $\mathrm{Age}^{\wedge} 2$ & -0.0023 & $* * *$ & $(0.0003)$ & -0.0028 & $* * *$ & $(0.0004)$ \\
\hline Head of household & 0.3840 & $* * *$ & $(0.1392)$ & 0.6311 & $* * *$ & $(0.1700)$ \\
\hline \multicolumn{7}{|l|}{ Education } \\
\hline Medium education & 0.1751 & & $(0.1579)$ & 0.3663 & $*$ & $(0.2020)$ \\
\hline High education & 0.4376 & $* * *$ & $(0.1671)$ & 0.6590 & $* * *$ & $(0.2068)$ \\
\hline \multicolumn{7}{|l|}{ Family characteristics } \\
\hline Married & -0.2328 & & $(0.1525)$ & -0.0731 & & $(0.2303)$ \\
\hline Living together & -0.5366 & $*$ & $(0.2928)$ & 0.7426 & & $(0.5805)$ \\
\hline Separated & -0.1863 & & $(0.2399)$ & -0.3671 & & $(0.3177)$ \\
\hline Widower & -0.1032 & & $(0.2168)$ & -0.2499 & & $(0.3175)$ \\
\hline Prop. of indiv. in household aged $0-5$ & -0.9895 & $* *$ & $(0.3949)$ & -0.3077 & & $(0.4614)$ \\
\hline Prop. of indiv . in household aged 6-16 & -0.4115 & & $(0.3948)$ & 0.1002 & & $(0.4845)$ \\
\hline \multicolumn{7}{|l|}{ Prop. of indiv . in household aged 66 or } \\
\hline Constant & -2.5402 & $* * *$ & $(0.5790)$ & -4.4380 & $* * *$ & $(0.6486)$ \\
\hline Inverse Mill's ratio & -0.1495 & $*$ & $(0.0815)$ & 0.1635 & & $(0.1093)$ \\
\hline F-Statistics & \multicolumn{3}{|c|}{$15.19 * * *$} & \multicolumn{3}{|c|}{$11.15^{* * *}$} \\
\hline Number of individuals & \multicolumn{3}{|c|}{992} & \multicolumn{3}{|c|}{835} \\
\hline
\end{tabular}

Notes. (1) The symbols *, ** and *** indicate significance at the $10 \%, 5 \%$ and $1 \%$ levels, respectively.

(2) Weights have been used for the estimation.

(3) The reported standard errors are robust to misspecification. 
Table 4

Determinants of monthly earnings of Russians and Kazakhs in 2010: OLS estimation

\begin{tabular}{|c|c|c|c|c|c|c|}
\hline & \multicolumn{3}{|l|}{ Russians } & \multicolumn{3}{|l|}{ Kazakhs } \\
\hline & \multicolumn{2}{|l|}{ Estimate } & \multirow[t]{2}{*}{ S.E. } & \multicolumn{2}{|l|}{ Estimate } & \multirow[t]{2}{*}{ S.E. } \\
\hline Labor market characteristics & & & & & & \\
\hline Self-employed & 0.2652 & $* *$ & $(0.1222)$ & 0.1931 & * & $(0.1149)$ \\
\hline State enterprise & -0.0858 & $*$ & $(0.0457)$ & -0.0855 & & $(0.0539)$ \\
\hline Hours per week & 0.0078 & $* * *$ & $(0.0018)$ & 0.0034 & $*$ & $(0.0019)$ \\
\hline \multicolumn{7}{|l|}{ Socio-demographic characteristics } \\
\hline Male & 0.2991 & $* * *$ & $(0.0438)$ & 0.1696 & $* * *$ & $(0.0525)$ \\
\hline Age & 0.0386 & $* * *$ & $(0.0115)$ & 0.0253 & $*$ & $(0.0151)$ \\
\hline $\mathrm{Age}^{\wedge} 2$ & -0.0004 & $* * *$ & $(0.0001)$ & -0.0003 & $*$ & $(0.0002)$ \\
\hline Head of household & 0.0981 & $* *$ & $(0.0442)$ & 0.0824 & & $(0.0592)$ \\
\hline \multicolumn{7}{|l|}{ Occupation } \\
\hline Professionals & -0.1441 & $*$ & $(0.0734)$ & -0.0556 & & $(0.0705)$ \\
\hline Technicians and associate professionals & -0.1508 & & $(0.0916)$ & 0.0214 & & $(0.0798)$ \\
\hline Clerical support workers & -0.2172 & $* * *$ & $(0.0793)$ & -0.1700 & $*$ & $(0.0888)$ \\
\hline Service and sales workers & -0.2423 & $* * *$ & $(0.0815)$ & -0.2486 & *** & $(0.0821)$ \\
\hline \multicolumn{7}{|l|}{ Skilled agriculture., forestry and fishery } \\
\hline Craft and related trades workers & -0.2563 & $* * *$ & $(0.0780)$ & -0.0117 & & $(0.0915)$ \\
\hline \multicolumn{7}{|l|}{ Plant and machine operators, and } \\
\hline Elementary occupations & -0.3481 & $* * *$ & $(0.0775)$ & -0.2588 & $* * *$ & $(0.0879)$ \\
\hline Armed forces occupations & -0.0243 & & $(0.1747)$ & -0.0145 & & $(0.0918)$ \\
\hline \multicolumn{7}{|l|}{ Sector } \\
\hline Mining & 0.6466 & $* * *$ & $(0.1337)$ & 0.1286 & & $(0.1625)$ \\
\hline Manufacturing & 0.1705 & $*$ & $(0.0977)$ & 0.1370 & & $(0.1375)$ \\
\hline Utilities & 0.2098 & $*$ & $(0.1172)$ & 0.0214 & & $(0.166)$ \\
\hline Construction & 0.2392 & $* *$ & $(0.1013)$ & 0.0667 & & $(0.1408)$ \\
\hline Services/other & 0.1370 & & $(0.0874)$ & -0.0023 & & $(0.1229)$ \\
\hline \multicolumn{7}{|l|}{ Education } \\
\hline Medium education & 0.2092 & $* * *$ & $(0.0562)$ & 0.1480 & $* *$ & $(0.0741)$ \\
\hline High education & 0.4288 & $* * *$ & $(0.0657)$ & 0.3459 & $* * *$ & $(0.0818)$ \\
\hline \multicolumn{7}{|l|}{ Location } \\
\hline Astana & 0.0329 & & $(0.0579)$ & 0.1286 & $* *$ & $(0.0584)$ \\
\hline Karaganda & -0.3172 & $* * *$ & $(0.0561)$ & -0.0997 & & $(0.0676)$ \\
\hline Pavlodar & -0.3094 & $* * *$ & $(0.0543)$ & -0.2088 & $* * *$ & $(0.0694)$ \\
\hline Constant & 9.5019 & $* * *$ & $(0.2820)$ & 10.0725 & $* * *$ & $(0.3329)$ \\
\hline F-Statistics & \multicolumn{3}{|c|}{$24.31 * * *$} & \multicolumn{3}{|c|}{$13.11^{* * *}$} \\
\hline R-square & \multicolumn{3}{|c|}{0.4418} & \multicolumn{3}{|c|}{0.3065} \\
\hline Number of individuals & \multicolumn{3}{|c|}{637} & \multicolumn{3}{|c|}{597} \\
\hline
\end{tabular}

Notes. (1) The symbols *, ** and *** indicate significance at the $10 \%, 5 \%$ and $1 \%$ levels, respectively.

(2) Weights have been used for the estimation.

(3) The reported standard errors are robust to misspecification. 
Table 5

Decomposing the difference in monthly earnings of $-0.171 \mathrm{log}$ points between Kazakhs and Russians in 2010

\begin{tabular}{|c|c|c|c|c|c|c|}
\hline & \multicolumn{3}{|c|}{ Characteristics effect } & \multicolumn{3}{|c|}{ Coefficients effect } \\
\hline & Estimate & & Share & Estimate & & Share \\
\hline Aggregate Effect & 0.0414 & $* * *$ & -24.28 & -0.2119 & $* * *$ & 124.28 \\
\hline Aggregate effect without constants & & & & 0.0577 & & -33.82 \\
\hline Labor market characteristics & -0.0093 & & 5.43 & -0.1959 & $*$ & 114.87 \\
\hline Self-employed & -0.0006 & $*$ & 0.35 & -0.0036 & & 2.13 \\
\hline State enterprise & -0.0117 & $*$ & 6.87 & -0.0013 & & 0.77 \\
\hline Hours per week & 0.0031 & $*$ & -1.80 & -0.1909 & $*$ & 111.98 \\
\hline Socio-demographic characteristics & 0.0396 & $* * *$ & -23.20 & 0.1595 & & -93.52 \\
\hline Male & 0.0132 & $* * *$ & -7.76 & -0.0389 & & 22.81 \\
\hline Age & -0.0735 & $* *$ & 43.13 & 0.6962 & & -408.32 \\
\hline $\mathrm{Age}^{\wedge} 2$ & 0.0977 & $* *$ & -57.28 & -0.5477 & & 321.19 \\
\hline Head of household & 0.0022 & $*$ & -1.28 & 0.0498 & & -29.20 \\
\hline Occupation & 0.0051 & & -2.97 & 0.0462 & $*$ & -27.11 \\
\hline Managers & 0.0009 & $* *$ & -0.53 & -0.0033 & & 1.94 \\
\hline Professionals & 0.0020 & & -1.19 & 0.0103 & & -6.02 \\
\hline Technicians and associate professionals & -0.0015 & $* * *$ & 0.87 & 0.0104 & * & -6.11 \\
\hline Clerical support workers & -0.0001 & & 0.09 & 0.0016 & & -0.94 \\
\hline Service and sales workers & -0.0012 & $*$ & 0.71 & -0.0048 & & 2.82 \\
\hline Skilled agriculture., forestry and fishery & & & & & & \\
\hline workers & -0.0011 & $* * *$ & 0.67 & -0.0004 & $* *$ & 0.23 \\
\hline Craft and related trades workers & -0.0035 & $* *$ & 2.03 & 0.0315 & $* * *$ & -18.48 \\
\hline $\begin{array}{l}\text { Plant and machine operators, and } \\
\text { assemblers }\end{array}$ & 0.0017 & & -1.01 & -0.0085 & & 4.98 \\
\hline Elementary occupations & 0.0028 & $* *$ & -1.65 & 0.0097 & & -5.68 \\
\hline Armed forces occupations & 0.0051 & $*$ & -2.96 & -0.0002 & & 0.13 \\
\hline Sector & -0.0033 & & 1.93 & 0.0331 & & -19.39 \\
\hline Agriculture & -0.0004 & & 0.22 & 0.0014 & & -0.81 \\
\hline Mining & 0.0000 & & -0.01 & -0.0097 & $* * *$ & 5.69 \\
\hline Manufacturing & -0.0022 & & 1.30 & 0.0155 & $*$ & -9.11 \\
\hline Utilities & 0.0014 & & -0.85 & -0.0013 & & 0.74 \\
\hline Construction & 0.0002 & & -0.14 & 0.0004 & & -0.22 \\
\hline Services/other & -0.0024 & & 1.40 & 0.0267 & & -15.68 \\
\hline Education & 0.0248 & $* * *$ & -14.53 & -0.0037 & & 2.15 \\
\hline Low education & 0.0038 & $* * *$ & -2.24 & 0.0005 & & -0.29 \\
\hline Medium education & 0.0012 & & -0.70 & -0.0066 & & 3.87 \\
\hline High education & 0.0198 & $* * *$ & -11.59 & 0.0024 & & -1.43 \\
\hline Location & -0.0154 & $* * *$ & 9.05 & 0.0184 & $*$ & -10.82 \\
\hline Astana & 0.0007 & & -0.41 & -0.0124 & $* *$ & 7.27 \\
\hline Almaty & -0.0082 & $* * *$ & 4.80 & -0.0021 & & 1.24 \\
\hline Karaganda & 0.0014 & & -0.84 & 0.0325 & $* *$ & -19.04 \\
\hline Pavlodar & -0.0094 & $* * *$ & 5.49 & 0.0005 & & -0.29 \\
\hline Constant & & & & -0.2696 & & 158.10 \\
\hline Number of individuals & & 992 & & & 835 & \\
\hline
\end{tabular}


Notes. (1) Share refers to the ratio of the contribution of each factor to the overall differences in monthly earnings of $-0.171 \log$ points between Kazakhs and Russians; it is expressed as a percentage of this difference.

(2) The symbols *,** and *** indicate significance at the $10 \%, 5 \%$ and $1 \%$ levels, respectively.

(3) The decomposition is based on the Heckit estimation of Table 3. 
Table 6

Decomposing the difference in monthly earnings between Kazakhs and Russians in 1991, 2010 and 2010

\begin{tabular}{|c|c|c|c|c|c|c|}
\hline \multirow[t]{3}{*}{1991 (based on OLS estimation) } & \multicolumn{6}{|c|}{ Difference in monthly earnings: $0.089 \log$ points } \\
\hline & \multicolumn{3}{|c|}{ Characteristics effect } & \multicolumn{3}{|c|}{ Coefficients effect } \\
\hline & \multicolumn{2}{|c|}{ Estimate } & Share & \multicolumn{2}{|c|}{ Estimate } & Share \\
\hline Aggregate Effect & \multicolumn{2}{|l|}{0.0691} & \multirow[t]{2}{*}{77.85} & \multicolumn{2}{|l|}{0.0197} & 22.15 \\
\hline Aggregate effect without constants & & & \multicolumn{2}{|l|}{0.6496} & 731.87 \\
\hline Labor market characteristics & \multicolumn{2}{|l|}{0.0241} & 27.15 & \multicolumn{2}{|l|}{0.3923} & 441.97 \\
\hline Socio-demographic characteristics & \multicolumn{2}{|l|}{0.0804} & 90.63 & \multicolumn{2}{|l|}{0.5082} & 572.61 \\
\hline Occupation & \multicolumn{2}{|l|}{-0.0269} & -30.30 & \multicolumn{2}{|l|}{0.2588} & 291.60 \\
\hline Sector & \multicolumn{2}{|l|}{-0.0364} & -40.99 & \multicolumn{2}{|l|}{-0.2130} & -239.95 \\
\hline Education & \multicolumn{2}{|l|}{0.0240} & 27.06 & \multicolumn{2}{|l|}{-0.1193} & -134.42 \\
\hline Location & \multirow{2}{*}{\multicolumn{2}{|c|}{0.0038}} & 4.31 & \multicolumn{2}{|l|}{-0.1775} & -199.95 \\
\hline Constant & & & & \multicolumn{2}{|l|}{-0.6299} & -709.72 \\
\hline Number of individuals & \multicolumn{3}{|c|}{463} & & 274 & \\
\hline 2001 (based on OLS estimation) & Differen & in & nonthly e & $.087 \log 1$ & oint & \\
\hline & Characte & istic & effect & Coefficie & nts $C$ & fect \\
\hline & Estimate & & Share & Estimate & & Share \\
\hline Aggregate Effect & 0.0514 & & 58.87 & 0.0359 & & 41.13 \\
\hline Aggregate effect without constants & & & & 0.0320 & & 36.56 \\
\hline Labor market characteristics & -0.0091 & & -10.39 & -0.3247 & & -371.56 \\
\hline Socio-demographic characteristics & 0.0534 & ** & 61.16 & 0.5724 & & 655.04 \\
\hline Occupation & 0.0252 & $* *$ & 28.87 & -0.0136 & & -15.54 \\
\hline Sector & 0.0027 & & 3.05 & -0.1983 & $* *$ & -226.94 \\
\hline Education & 0.0139 & & 15.92 & 0.0267 & & 30.53 \\
\hline Location & -0.0347 & ** & -39.74 & -0.0305 & & -34.96 \\
\hline Constant & & & & 0.0040 & & 4.57 \\
\hline Number of individuals & & 565 & & & 437 & \\
\hline 2010 (based on OLS estimation) & Differen & in & nonthly er & $0.047 \log$ & ooin & \\
\hline & Characte & istic & effect & Coefficie & nts $\epsilon$ & fect \\
\hline & Estimate & & Share & Estimate & & Share \\
\hline Aggregate Effect & 0.0301 & $* * *$ & -63.67 & -0.0774 & $* *$ & 163.67 \\
\hline Aggregate effect without constants & & & & -0.5586 & & 1181.1 \\
\hline Labor market characteristics & -0.0088 & & 18.58 & -0.1963 & $*$ & 415.01 \\
\hline Socio-demographic characteristics & 0.0299 & $* * *$ & -63.24 & -0.4402 & & 930.65 \\
\hline Occupation & 0.0048 & & -10.25 & 0.0461 & $*$ & -97.55 \\
\hline Sector & -0.0033 & & 6.91 & 0.0314 & & -66.45 \\
\hline Education & 0.0221 & $* * *$ & -46.66 & -0.0158 & & 33.50 \\
\hline Location & -0.0147 & $* * *$ & 30.99 & 0.0162 & & -34.23 \\
\hline Constant & & & & 0.4811 & & -1017.3 \\
\hline
\end{tabular}

Notes. (1) Share refers to the ratio of the contribution of each factor to the overall differences in monthly earnings between Kazakhs and Russians; it is expressed as a percentage of this difference.

(2) The symbols *, ** and *** indicate significance at the $10 \%, 5 \%$ and $1 \%$ levels, respectively. 
Table 7

Decomposing the difference in monthly earnings between Kazakhs and Russians in 2010 (sensitivity)

\begin{tabular}{|c|c|c|c|c|c|c|}
\hline \multirow[t]{3}{*}{ Without weights } & \multicolumn{6}{|c|}{ Difference in monthly earnings: $-0.247 \log$ points } \\
\hline & \multicolumn{3}{|c|}{ Characteristics effect } & \multicolumn{3}{|c|}{ Coefficients effect } \\
\hline & \multicolumn{2}{|c|}{ Estimate } & \multirow{2}{*}{$\begin{array}{c}\text { Share } \\
-50.29\end{array}$} & \multicolumn{2}{|c|}{ Estimate } & Share \\
\hline Aggregate Effect & 0.1242 & $* * *$ & & -0.3711 & $* * *$ & 150.29 \\
\hline Aggregate effect without constants & & & & 0.8111 & & -328.50 \\
\hline Labor market characteristics & -0.0149 & $* * *$ & 6.03 & -0.1343 & & 54.38 \\
\hline Socio-demographic characteristics & 0.0470 & $* * *$ & -19.02 & 0.8764 & & -354.92 \\
\hline Occupation & 0.0107 & $*$ & -4.35 & 0.0300 & & -12.15 \\
\hline Sector & -0.0062 & & 2.49 & 0.0151 & & -6.10 \\
\hline Education & 0.0356 & $* * *$ & -14.40 & 0.0154 & & -6.25 \\
\hline Location & 0.0520 & $* * *$ & -21.05 & 0.0085 & ** & -3.46 \\
\hline Constant & & & & -1.1823 & $*$ & 478.79 \\
\hline Number of individuals & & 637 & & & 597 & \\
\hline \multirow[t]{3}{*}{ 'Balanced' sample } & \multicolumn{6}{|c|}{ Difference in monthly earnings: $-0.2855 \log$ points } \\
\hline & \multicolumn{3}{|c|}{ Characteristics effect } & \multicolumn{3}{|c|}{ Coefficients effect } \\
\hline & \multicolumn{2}{|c|}{ Estimate } & Share & \multicolumn{2}{|c|}{ Estimate } & Share \\
\hline Aggregate Effect & 0.0664 & $* * *$ & -23.24 & -0.3519 & $* * *$ & 123.24 \\
\hline Aggregate effect without constants & & & & 1.2109 & & -424.10 \\
\hline Labor market characteristics & -0.0007 & & 0.24 & -0.3603 & ** & 126.17 \\
\hline Socio-demographic characteristics & 0.0593 & $* * *$ & -20.76 & 1.5175 & & -531.47 \\
\hline Occupation & -0.0003 & & 0.09 & 0.0260 & & -9.12 \\
\hline Sector & -0.0021 & & 0.72 & 0.0157 & & -5.48 \\
\hline Education & 0.0192 & $* *$ & -6.71 & -0.0074 & & 2.58 \\
\hline Location & -0.0091 & $* *$ & 3.18 & 0.0193 & & -6.77 \\
\hline Constant & & & & -1.5628 & & 547.34 \\
\hline Number of individuals & & 350 & & & 315 & \\
\hline \multirow[t]{3}{*}{ Kazakh coefficients } & \multicolumn{6}{|c|}{ Difference in monthly earnings: -0.1705 log points } \\
\hline & \multicolumn{3}{|c|}{ Characteristics effect } & \multicolumn{3}{|c|}{ Coefficients effect } \\
\hline & \multicolumn{2}{|c|}{ Estimate } & Share & \multicolumn{2}{|c|}{ Estimate } & Share \\
\hline Aggregate Effect & 0.0428 & $* * *$ & -25.08 & -0.2133 & $* * *$ & 125.08 \\
\hline Aggregate effect without constants & & & & 0.0563 & & -33.02 \\
\hline Labor market characteristics & -0.0050 & & 2.96 & -0.2001 & & 117.34 \\
\hline Socio-demographic characteristics & 0.0240 & $* * *$ & -14.09 & 0.1750 & & -102.63 \\
\hline Occupation & 0.0127 & $*$ & -7.43 & 0.0386 & $*$ & -22.66 \\
\hline Sector & -0.0026 & & 1.55 & 0.0324 & & -19.01 \\
\hline Education & 0.0233 & $* * *$ & -13.68 & -0.0022 & & 1.30 \\
\hline Location & -0.0096 & $* * *$ & 5.61 & 0.0126 & & -7.38 \\
\hline Constant & & & & -0.2696 & & 158.10 \\
\hline Number of individuals & & 637 & & & 597 & \\
\hline
\end{tabular}

Notes. (1) Share refers to the ratio of the contribution of each factor to the overall differences in monthly earnings between Kazakhs and Russians; it is expressed as a percentage of this difference.

(2) The symbols *, ** and *** indicate significance at the $10 \%, 5 \%$ and $1 \%$ levels, respectively. 